\title{
Otolaryngology litigation in England: 727 clinical negligence cases against the NHS
}

\author{
Annakan Navaratnam ${ }^{1}$, Ahmad Hariri², Cherrie $\mathrm{Ho}^{3}$, John Machin ${ }^{3}$, Andrew Marshall ${ }^{4}$, \\ and Tim Briggs ${ }^{3}$ \\ ${ }^{1}$ NHS England \& NHS Improvment \\ ${ }^{2}$ University College London Hospitals NHS Foundation Trust \\ ${ }^{3}$ NHS England \& NHS Improvement \\ ${ }^{4}$ Queen's Medical Centre
}

June 19, 2020

\begin{abstract}
Introduction: Litigation against the National Health Service (NHS) in England is rising, costing £2.4 billion in 2018/19. The aim of this study was to determine the incidence and characteristics of otolaryngology clinical negligence claims in England. Methods: A retrospective review was undertaken of all clinical negligence claims in England held by NHS Resolution relating to otolaryngology between April 2013 and April 2018. Analysis was performed using information for cause, patient injury and claim cost. Where claim information was adequately detailed, the authors categorised claims by subspecialty, diagnosis and operation. Results: A total of 727 claims were identified with an estimated potential cost of $£ 108$ million. From these, 463 were closed claims. Including open claim reserves, the mean cost of a claim was $£ 148,923$. Head and neck surgery was the subspecialty with the highest number of claims $(n=313,43 \%)$ and highest cost ( $£ 51.5$ million) followed by otology ( $\mathrm{n}=171$, $£ 24.5$ million) and rhinology ( $\mathrm{n}=171, £ 13.6$ million). Over half of claims were associated with an operation $(\mathrm{n}=429,59 \%)$ where mastoid surgery $(n=46)$ and endoscopic sinus surgery $(n=46)$ were equally associated with the greatest number of claims. The most frequent reasons for litigation included failure or delay to diagnose $(n=178,25 \%)$ failure or delay to treat $(n=136,19 \%)$, intra-operative complications $(n=130,18 \%)$ and failure of the consent process $(n=107,15 \%)$. Discussion: Clinical negligence claims in otolaryngology are related to several different components of patient management and is not limited to post-operative complications. This study highlights the importance of robust pathways in outpatient diagnostics and the consenting process, especially in the high-risk speciality of head and neck surgery, in order to deliver better patient care and reduce the impact of litigation.
\end{abstract}

\section{Hosted file}

Otolaryngology_litigation___Main_document (1).doc available at https://authorea.com/users/ 335032/articles/460950-otolaryngology-litigation-in-england-727-clinical-negligencecases-against-the-nhs

\section{Hosted file}

Table 1 Otolaryngology clinical negligence claims.doc available at https://authorea. com/users/335032/articles/460950-otolaryngology-litigation-in-england-727-clinicalnegligence-cases-against-the-nhs

\section{Hosted file}

Table 2 Clinical negligence claim cost and volume for surgical specialties.doc available at https://authorea. com/users/335032/articles/460950-otolaryngology-litigation-in-england- 
727-clinical-negligence-cases-against-the-nhs

\section{Hosted file}

Table 3 Otolaryngology clinical negligence claims cause and injury codes.doc available at https: //authorea.com/users/335032/articles/460950-otolaryngology-litigation-in-england727-clinical-negligence-cases-against-the-nhs
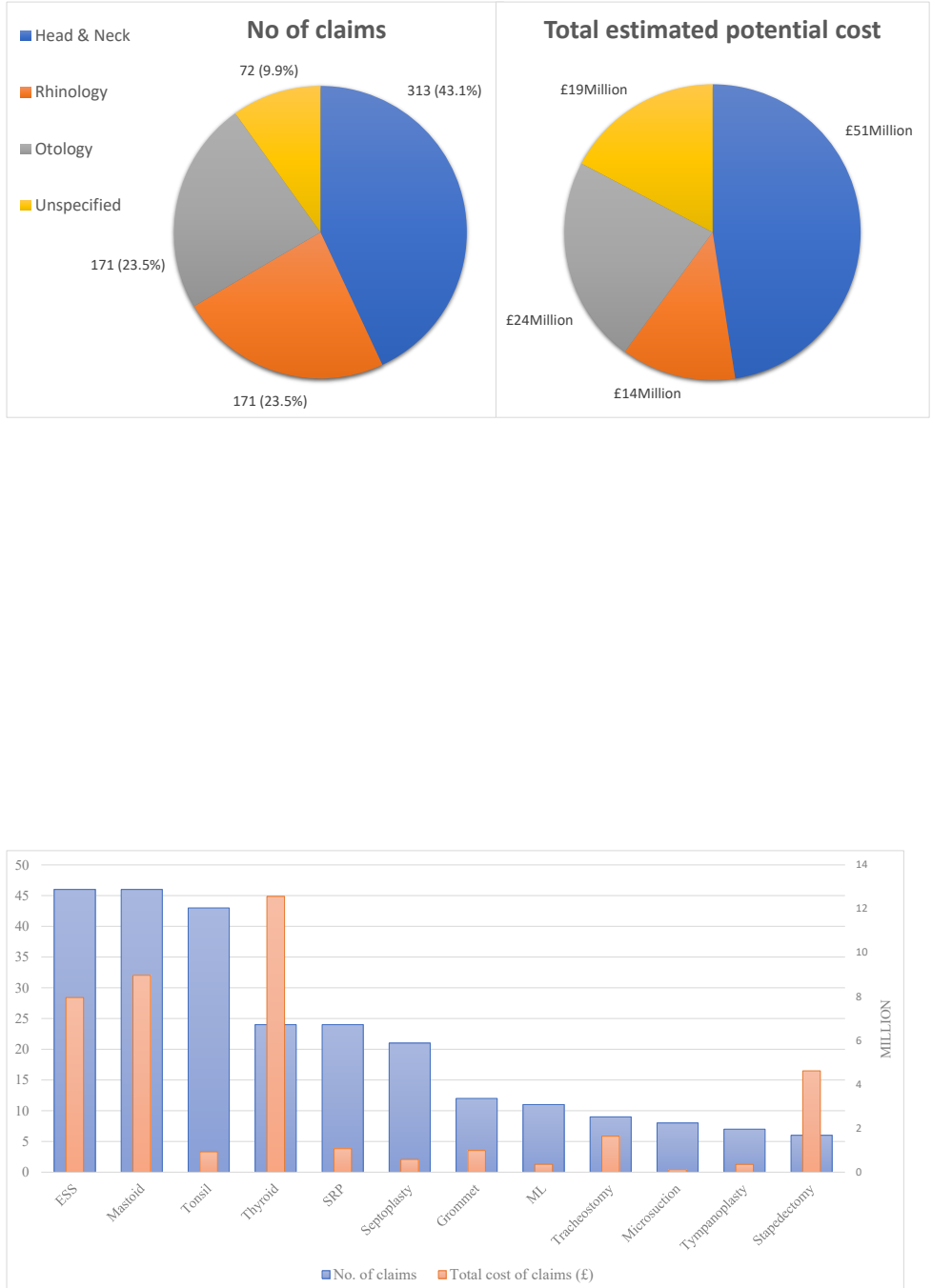